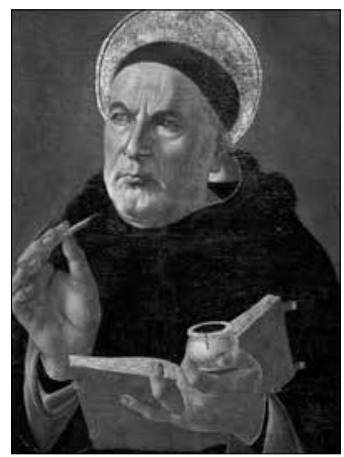

\title{
SVARSTYTI KLAUSIMAI APIE TIESA KLAUSIMAS XV. 2 ARTIKULAS
}

Disputed Questions on Truth. Question 15. Article 2

\author{
ANTRAS ARTIKULAS \\ KLAUSIAMA, AR AUKŠTESNYSIS IR ŽEMESNYSIS PROTAS \\ YRA SKIRTINGOS GALIOS
}

Ir atrodo, kad skirtingos, nes

1. Augustinas traktato Apie Trejybę dvyliktoje knygoje rašo, kad Trejybès vaizdinys yra aukštesniojoje, o ne žemesniojoje proto dalyje (Augustinus 1841: lib. XII, cap. 4). Bet Dievo vaizdinys sieloje priklauso trims galioms. Vadinasi, žemesnysis protas nepriklauso toms pačioms galioms, kurioms priklauso aukštesnysis. Todèl atrodo, kad jie yra skirtingos galios.

2. Be to, kadangi dalys vadinamos atsižvelgiant į visuma, tai bet kurioje giminèje dalys atrandamos tuo pačiu būdu kaip ir visuma. Tačiau sakoma, kad siela tik galimai yra visuma. Vadinasi, ir skirtingos sielos dalys yra skirtingos galios. Bet aukštesnijji ir žemesnijji protą Augustinas vadina skirtingomis proto dalimis. Todèl jie yra skirtingos galios.

3. Be to, anot Filosofo Metafizikos devintosios knygos, visa, kas amžina, būtina, o visa, kas kintama ir laikina, yra atsitiktina (Aristotle 1941c.: 831 [1050b 15-35]). Tačiau ta sielos dalis, kuri, anot Filosofo Etikos šeštosios knygos, vadinama žinančiąja, užsiima būtinais dalykais, o protaujanti ir nuomones formuojanti dalis - atsitiktiniais (Aristotelis 1990b.: 170 [1139a 5]). Ir kadangi, anot Augustino, aukštesny- 
sis protas užsiima amžinaisiais dalykais, o žemesnysis tvarko laikinus bei irius, tai atrodo, kad protaujančioji sielos dalis yra tapati žemesniajam protui, o žinančioji aukštesniajam. Tačiau Filosofas toje pat jau cituotos knygos vietoje teigia, kad žinančioji ir protaujančioji sielos dalys yra skirtingos galios (ten pat). Vadinasi, ir aukštesnysis bei žemesnysis protas yra skirtingos galios.

4. Be to, toje pat vietoje Filosofas rašo, kad tos sielos dalys, iš kuriu viena yra nukreipta $i$ viena būties forma, kita - $i$ kita, giminès atžvilgiu taip pat yra skirtingos (ten pat), nes kiekviena, tam tikrai giminei skirta sielos dalis jai skirta dèl tam tikro panašumo. Todèl gimininis objektų skirtingumas patvirtina galių skirtingumą. Bet tai, kas amžina, ir tai, kas netvaru, priklauso visiškai skirtingoms giminėms, nes dešimtoje Metafizikos knygoje rašoma, kad netvarus ir tvarus gimineje nesusitinka (Aristotle 1941c.: 849 [1058b 25]). Vadinasi, aukštesnysis protas, kurio objektas yra amžinieji dalykai, yra kita galia negu žemesnysis protas, kurio medžiaga yra netvarūs daiktai.

5. Be to, galios skirstomos pagal veiksmus, o veiksmai - pagal objektus. Bet skirtingi objektai yra mąstytina tiesa ir darytinas gèris. Vadinasi, skirtingos galios yra tiesą apmąstantis aukštesnysis protas ir gèri darantis žemesnysis protas.

6. Be to, tas, kuris savyje nèra vienas, palyginti su kitais, dar mažiau yra vienas. Tačiau aukštesnysis protas nèra viena galia, bet daug galių, nes jame yra iš triju galių susidedanti vaizduotè. Todèl negalima teigti, kad aukštesnysis ir žemesnysis protas yra viena galia.

7. Be to, protas yra paprastesnis negu jutimas. Tačiau jutiminėje sielos dalyje nèra taip, kad ta pati galia atliktų skirtingas funkcijas. Vadinasi, dar mažiau tikètina, kad protaujančioje dalyje esanti viena galia turètų atlikti skirtingas funkcijas. Tačiau, anot Augustino traktato Apie Trejybę dvyliktos knygos, i aukštesni ir žemesni protas dalijamas pagal atliekamas funkcijas. Vadinasi, jie yra skirtingos galios (Augustinus 1841: lib. XII, cap. 3).

8. Be to, kada tik sielai priskiriama kas nors, ko neimanoma redukuoti ${ }^{1} \mathfrak{i}$ tą pati prada, tada būtina sielai priskirti skirtingas galias, pavyzdžiui, prièmimo ir išlaikymo priskyrimas vaizduotę atskiria nuo jutimo. Tačiau amžino ir laikino neimanoma redukuoti $i$ tą pati jiems artimą prada, kaip tai įrodyta Metafizikos vienuoliktoje knygoje (Aristotle 1941c.: 872 [1069a 30]). Vadinasi, juos reikia priskirti ne toms pačioms sielos galioms, ir taip aukštesnysis ir žemesnysis protas yra skirtingos sielos galios.

9. Be to, Augustinas traktato Apie Trejybę dvyliktoje knygoje rašo, kad pirmojoje žmogaus nuodėmėje dalyvavo trys - vyras, moteris ir žaltys. Autorius teigia, kad šie trys mumyse žymi aukščiausiąji prota, žemesnijji protą ir juslumą (Augustinus 1841: lib. XII, cap. 17).

Tačiau juslumas yra kita galia negu žemesnysis protas. Vadinasi, ir žemesnysis protas yra kita galia negu aukštesnysis protas.

10. Be to, viena galia tuo pat metu negali nusidèti ir nenusidèti. Tačiau žemesnysis protas kartais nusideda tada, kai aukštesnysis nenusideda, kaip tai matyti iš to, kas parašyta Augustino traktate Apie Trejybę (ten pat). Vadinasi, žemesnysis ir aukštesnysis protas nèra viena galia. 
11. Be to, skirtingi tobulumai priklauso skirtingiems, tobulèti galintiems objektams, nes tinkamam veiksmui reikia tinkamos galios. Tačiau sielos gebejjimai yra galiu tobulumai. Vadinasi, skirtingi gebëjimai priklauso skirtingoms galioms. Bet, Augustino teigimu, aukštesnysis protas priskiriamas išminčiai, o žemesnysis - mokslui, t. y. skirtingiems gebẻjimams. Taigi aukštesnysis ir žemesnysis protas irgi yra skirtingos galios.

12. Be to, kiekviena galia tobulëja per savo veiklą. O veiklu i̇vairové aprèpia arba parodo galių ivvairovę. Vadinasi, visur, kur tik sutinkama veiklų ìvairovė, reikia spręsti apie galiu ịvairovę. Tačiau aukštesniajam ir žemesniajam protui priklauso skirtingos veiklos, nes, anot Augustino, jos atlieka dvi skirtingas funkcijas. Todèl aukštesnysis ir žemesnysis protas yra skirtingos galios.

13. Be to, aukštesnysis ir žemesnysis protas skiriasi labiau negu aktyvusis ir pasyvusis mąstymas, nes jie abu veikia su tuo pačiu mąstomu objektu, o aukštesnysis ir žemesnysis protas veikia ne su tuo pačiu, bet, kaip jau minèta, su skirtingais objektais. Tačiau aktyvusis ir pasyvusis mąstymas yra skirtingos galios. Vadinasi, aukštesnysis ir žemesnysis protas irgi yra skirtingos galios.

14. Be to, visa, kas kildinama iš kito, nuo jo skiriasi, nes niekas negali būti savo paties priežastimi. $\mathrm{O}$ žemesnysis protas kildinamas iš aukštesniojo, kaip teigia Augustinas traktato Apie Trejybe dvyliktoje knygoje (ten pat, cap. 3). Vadinasi, jis yra kita galia negu aukštesnysis protas.

15. Be to, Fizikos septintoje knygoje įrodyta, kad niekas pats savęs nejudina (Aristotle 1941d.: 340 [241b 25]). Tačiau aukštesnysis protas žemesniji judina tiek, kiek ji tvarko ir jam vadovauja. Vadinasi, aukštesnysis ir žemesnysis protas yra skirtingos galios.

1. Bet yra priešingai. Skirtingos sielos galios yra skirtingi dalykai. Bet aukštesnysis ir žemesnysis protas nèra skirtingi dalykai. Todèl Augustinas traktato Apie Trejybę dvyliktoje knygoje rašo: kalbėdami apie žmogaus protinga siela (mens), iš tiesu kalbame tik apie viena dalyka, kurio nedalijame i tuos du, kuriuos minejjome, nebent tik per atliekamas funkcijas sudvejiname (Augustinus 1841: lib. XII, cap. 4). Todèl aukštesnysis ir žemesnysis protas nèra skirtingos galios.

2. Be to, kuo kuri nors galia yra mažiau medžiagiška, tuo daugiau gali apimti. O protas yra mažiau medžiagiškas negu jutimas. Tačiau ta pati jutimo galia (būtent rega) apima ir amžinus, tvarius, visais laikais esančius dangaus kūnus, ir tokius netvarius, kaip čia, žemiau egzistuojantys. Vadinasi, ta pati proto galia ir amžinus dalykus mąsto, ir laikinus tvarko.

Atsakymas. Norint $i \mathfrak{i ~ s ̌ i ~ k l a u s i m a ̨ ~ a t s a k y t i , ~ r e i k i a ~ z ̌ i n o t i ~ d u ~ d a l y k u s : ~ k a i p ~ s k i r s t o - ~}$ mos sielos galios ir kuo aukštesnysis protas skiriasi nuo žemesniojo, nes šiais dviem remiantis galima rasti atsakymą i dabar nagrinejjamą klausima, ar aukštesnysis ir žemesnysis protas yra ta pati galia, ar skirtingos galios.

Todèl reikia žinoti, jog galios skirstomos pagal ju veiklas ir objektus. Tačiau vieni sako, kad veiksmai ir objektai nėra galiu ivvairovès priežastys, o tik ju skirtingumo ženklai. O kiti teigia, kad objektu ivvairovė yra pasyviujų bet ne aktyviujų galių ìvairovès priežastis. 
Bet jeigu klausimą nagrinètume atidžiai, tai kiekvienoje galioje galètume matyti veiklą ir objektą esant ne tik kaip skirtingumo ženkla, bet ir tam tikru būdu kaip priežastị. Mat kiekvienas, kuris egzistuoja dèl kurio nors tikslo, turi tam tikra, tuo tikslu nulemtą būdą. Pavyzdžiui, pjūklas savo medžiaga ir pavidalu tinka jam skirtam tikslui - pjauti. Tačiau, kaip sakoma Metafizikos devintojoje knygoje, kiekviena, tiek aktyvioji, tiek pasyvioji sielos galia kaip i tikslą nukreipta i veiklą (Aristotle 1941c.: 821 [1046b]). Todèl kiekviena galia turi apibrèžtą būdą ir rūšì, kad galètų tikti tai veiklai. Galios yra skirtingos todèl, kad skirtingoms veikloms reikia skirtingų kilmès pradų. Bet kadangi objektas su veikla siejamas kaip su tikslu, o tikslas, anot penktosios Fizikos knygos, lemia veiklos rūšì, tai būtina, kad ir veikla būtų skirstoma pagal objektus (Aristotle 1941d.: 301 [224b]). Todèl objektų skirtingumas lemia galių skirtingumą.

Tačiau objektų ivvairovę galima skirstyti dvejopai: vienaip pagal daiktų prigimti, kitaip pagal skirtingas objektų sampratas: pirmuoju būdu skirstoma kaip spalva ir skonis, antruoju - kaip gèris ir tiesa. Bet kadangi tos galios, kurios yra tam tikru organų veiklos, negali išeiti už savo organų veiklos ribų, nes tas pats kūno organas negali būti pritaikytas visų prigimčių suvokimui. Todèl neišvengiama būtinybè reikalauja, kad tų organų galios būtų skirtos tam tikrų apibrèžtų prigimčių suvokimui, būtent kūniškų prigimčių. Mat kūno organais atliekama veikla negali pranokti kūniškos prigimties ribų.

Bet kūniškoje prigimtyje yra tai, kas visiems kūnams bendra, ir tai, kas juos vieną nuo kito skiria, todèl bus įmanoma viena, kūnui priskirtą galią pritaikyti visiems kūnams remiantis tuo, kas jiems yra bendra, pavyzdžiui, vaizduotę, atsižvelgiant $i$ tai, kad visus kūnus sieja kiekybès, [geometrinès] figūros ir padarinių sampratos. Todèl vaizduotè apima ne tik natūralius, bet ir matematinius objektus, o bendrasis jutimas (sensus communis), atsižvelgiant $i \mathfrak{t}$ tai, kad visiems natūraliems kūnams, kuriuos vienintelius jis apima, priklauso poveikio arba jutimo pakeitimo galia.

O kitos galios pritaikytos tam, kuo savo poveikio jutimui būdu kūnai vienas nuo kito skiriasi. Todèl rega junta spalva, klausa - garsa, ir taip toliau. Dèl to, kad jutiminè sielos dalis savo veikloje naudojasi kūno organais, atsiranda dvi pasekmès: būtent, kad jai negalima priskirti kokios nors galios, kuri suvoktų visiems esiniams bendrą objekta, nes tokiu atveju ji pranoktų kūniškumą; antra pasekmè yra ta, kad joje galima rasti ịvairias galias, atitinkančias objektų prigimties įvairovę dèl būklès organų, galinčių būti prisitaikytais kuriai nors prigimčiai.

O ta sielos dalis, kuri savo veikloje kūno organu nesinaudoja, yra ne apribota, o begalinė tiek, kiek yra nemedžiaginè, ir jos galia apima visiems esiniams bendrą objektą. Todèl sakoma, kad mąstymo objektas yra tai, kas visų esiniu giminėse atrandama. O Filosofas rašo, kad mąstymas yra tai, kuo siela gali daryti viską ir kas gali tapti viskuo (Aristotelis 1990a.: 390 [429b 25], 395 [431b 20]). Todèl protingoje sielos dalyje galias skirstyti įmanoma ne pagal ìvairias objektu prigimtis, o tik pagal skirtingas ju sampratas tame pačiame daikte, su kuriuo siela veikia. Šitaip gèris ir tiesa mąstančioje sielos dalyje išskiria mąstymą ir valią nes tiesa i save mąstymą 
traukia kaip pavidalas, kadangi mąstymas turi būti apipavidalintas tuo, ką supranta, o gèris i save traukia valią kaip jos tikslas. Todèl Filosofas Metafizikos šeštojoje knygoje rašo, kad tiesa yra prote, o gèris - daiktuose, nes pavidalas yra viduje, o tikslas - išorèje (Aristotle 1941c.: 782 [1027b 25-30]). Juk ne tuo pačiu požiūriu tikslas ir pavidalas daiktą daro tobulą. Tad gèris ir tiesa turi ne tą pačią objekto sampratą.

Todèl mąstymas dar skirstomas ị aktyviai veikianti ir galimybeje esanti pasyvų. Iš tiesų ne ta pačia samprata mąstomas aktualiai esantis ir galimybejje esantis, arba veikiantis ir poveiki patiriantis objektas, nes aktualiai suprantamas yra pasyviojo mąstymo objektas, tarsi pats savaime iš galimybès išeinantis i aktualybę, o galimai suprantamas yra aktyviojo mąstymo objektas, dèl šio mąstymo veiklos tampantis aktualiai suprantamas.

Taigi aišku, kaip protingoje sielos dalyje galios gali būti skirstomos. O aukštesnysis ir žemesnysis protas irgi šitaip skirstomas. Juk vienos prigimtys yra už protingą sielą aukštesnès, o kitos - žemesnès. Ir kadangi visa, kas suprantama, suprantama suprantančiojo būdu, tai aukščiau sielos esančių dalykų supratimas yra už pačius dalykus žemesnis, o tų, kurie yra žemiau sielos, sieloje esantis supratimas yra už juos aukštesnis, nes joje patys daiktai turi kilnesni buvimą negu tą, kuri patys savyje turi.

Todèl su abiejų daiktų rūšimis siela turi skirtingus santykius, iš kurių kildinamos skirtingos funkcijos. Mat dèl to protas vadinamas aukštesniuoju, kad tiesiogiai apmąsto aukštesniųju daiktų prigimti ir tiesą arba iš jų perima veiklos sampratą tarsi veikimo pavyzdį. O dèl to, kad nukreiptas ì žemesniųjų daiktų stebejjimą mąstymu arba tvarkyma, vadinamas žemesniuoju protu. Tačiau abi prigimtis aukštesniąją ir žemesniąją - žmogaus siela suvokia bendruoju suprantamumo pagrindu: aukštesniąją dèl to, kad ji yra pati savyje nemedžiaginè, o žemesniają dèl to, kad sielos veikla ją nuo medžiagos atplèšia. Tad akivaizdu, kad aukštesniuoju ir žemesniuoju protu vadinamos ne skirtingos galios, o viena, bet skirtingai su skirtingais dalykais susijusi galia.

1. Todèl ì pirmajji argumentą atsakytina, kad, kaip jau minèta, svarstant klausimą apie protingą sielą (mens), Trejybės atvaizdas yra sielos galiose kaip šaknyje, bet visapusiškai - galių veikloje. Todèl teigiama, kad atvaizdas priklauso aukštesniajam, o ne žemesniajam protui.

2. I antrajji atsakytina, kad galios dalis ne visada reiškia skirtingą galią. Kartais galios dalis suvokiama pagal dali objektų, kurių kiekis gali būti dalijamas. Pavyzdžiui, jeigu kas nors gali pakelti šimtą svarų, tai sakoma, jog tas, kuris gali pakelti tik penkiasdešimt penkis svarus, turi tik dali pirmojo galios, nes ir vieno, ir kito galia priklauso tai pačiai galios rūšiai. Būtent todèl aukštesnioji ir žemesnioji proto dalys vadinamos proto dalimis, kad abi siejamos su ta objektų dalimi, kurią apmąsto tas, kuri visi kartu vadina protu.

3. I trečiajji atsakytina, kad žinojimas ir protavimas arba manymas nèra tas pat, kas aukštesnysis ir žemesnysis protas, nes ir apie žemesniąsias prigimtis, kurias žemesnysis protas stebi, galima padaryti būtinus, žinojimui priskirtinus sprendimus: 
antraip fizika ir matematika nebūtų mokslas. Panašiai ir aukštesnysis protas tam tikru būdu siejamas su nuo laisvo apsisprendimo priklausomais ir dèl to atsitiktiniais veiksmais: antraip aukštesniajam protui nebūtų priskiriama dèl tų veiksmų atsitinkanti nuodèmè. Taigi aukštesnysis protas nėra visiškai atskirtas nuo protaujančiojo arba manančiojo. Tačiau protaujančioji ir žinančioji dalys yra skirtingos galios, nes susijusios su skirtingos prigimties mąstomais objektais.

Kadangi bet kuri galios veikla nepranoksta savo objekto pajėgumo, tai toji veikla, kurios neįmanoma redukuoti i minèto objekto prigimtį, turi priklausyti kitai galiai, veikiančiai su kita objekto prigimtimi. Tačiau traktato Apie siela trečiojoje knygoje teigiama, kad mąstymo objektas yra tai, kas mąstoma (Aristotelis 1990a.: 391 [430a]). Todèl mąstymo veikla apima tiek, kiek gali apimti to, kas yra, pajègumas. Per ją tampa tvirtai žinomi pirmieji pradai, apie kuriuos žinant, tolesniu protavimu pasiekiamas išvadų žinojimas. Ir tą galia, kuriai skirta pačias išvadas išskaidyti i tai, kuo kas yra (quod quid est), Filosofas vadina moksline.

Tačiau egzistuoja tokie dalykai, kurių neįmanom išskaidyti i tai, kuo kas yra, dèl jų esaties neaiškumo, kaip yra atsitiktiniuose, kiek jie yra atsitiktiniai. Todèl tokie dalykai yra pažistami ne tuo, kuo jie yra ir kas yra tikrasis mąstymo objektas, bet kitu būdu - būtent tam tikru spejjimu apie tuos dalykus, apie kurios tikro žinojimo negalima turèti. Todèl jiems pažinti reikia kitos galios. Ir kadangi toji galia nepajègia tyrimo protu redukuoti iki pat jo ribos, prie kurios jis nurimtu, bet pasilieka tyrime tarsi judejjime, teikdama vien tik nuomonę apie tai, kas tiriama, todèl tarsi pagal savo veiklos rezultatą toji galia vadinama protaujančiąja arba manančiąa. Tačiau aukštesnysis ir žemesnysis protas skirstomas pagal pačias prigimtis ir todèl jie nèra skirtingos galios, kaip yra žinojimo ir manymo.

4. I ketvirtajji reikia atsakyti, kad žinojimo ir protavimo objektai priklauso skirtingoms pažinių dalykų giminėms, nes pažistami skirtingais pažinimo būdais. Tačiau amžini ir laikini dalykai yra skirtingi savo prigimtimi, bet ne pažinumo būdu, pagal kuri sprendžiama apie galios ir objekto atitiktį.

5. I penktajji atsakytina, kad mąstytina tiesa ir darytinas gèris priklauso skirtingoms galioms, būtent mąstymui ir valiai. Tačiau aukštesnysis ir žemesnysis protas taip neskirstomi, nes abu gali būti tiek teoriniai, tiek praktiniai, nors ir dèl skirtingu priežasčiu, kaip jau buvo parodyta. Todèl argumento išvados nèra teisingos.

6. I šeštaji atsakytina, jog tam, kuris savyje turi daugybę dalyku, niekas nedraudžia būti vienybejje su kitu, savyje daugybę dalyku turinčiu, jeigu abu savyje turi tą pačią daugybę, panašiai, kaip ši akmenų krūva ir ta akmenų sankaupa yra tas pats objektas. Ir šitaip aukštesnysis bei žemesnysis protas yra viena galia, nors tam tikra prasme abu savyje turi daugybę galiu, nes abu turi tas pačias galias. Sakoma, kad aukštesnysis protas turi daugybę galių, tačiau ne taip, tarsi pati jo galia būtų padalyta i daugybę galių, bet taip, kaip valia yra pajungta mąstymui: ne taip, tarsi valia ir mąstymas būtų viena galia, o taip, kad mąstomas suvokimas judina valią.

7. I septintajj atsakytina, kad ir jutimineje dalyje yra tam tikra viena, skirtingas funkcijas atliekanti jutimo galia, tokia kaip vaizduotè, kuri išsaugo tai, kas jutimu 
suvokta, ir daug kartu pateikia mąstymui. Bet kadangi kuo mažiau galia susijusi su medžiaga, tuo daugiau gali apimti, tai niekas nekliudo, kad mąstančiajai sielos daliai priklausanti ta pati galia atliktu skirtingas funkcijas, bet ne jutiminei sielos daliai priklausanti galia.

8. I aštuntaji atsakytina, kad nors to, kas amžina, ir to, kas laikina, negalima redukuoti i vieną artimą pradą, tačiau to, kas amžina ir to, kas laikina, pažinimas redukuojamas ị vieną pradą, nes tuo pačiu nemedžiagiškumo pagrindu mąstymas juos abu suvokia.

9. I devintajji atsakytina, kad kaip vyras ir moteris, tarp kurių buvo kūniška sueitis, priklauso žmogaus giminei, o žaltys nepriklauso, taip, anot Augustino traktato Apie Trejybę dvyliktosios knygos, aukštesniojo proto prigimčiai priklauso žemesnysis protas, kaip moteris, bet ne juslumas, kaip žaltys (Augustinus 1841: lib. XII, cap. 13).

10. I dešimtajji atsakytina, jog nuodèmè, tiesą sakant, nèra nei aukštesniojo, nei žemesniojo proto, o žmogaus veiksmas, vadovaujantis tuo ar anuo. Ir nėra nieko keista, jeigu viena galia siejama su skirtingais dalykais, kad vienam santykiui esant nuodėmè būtu, o esant kitam nebūtų, panašiai kaip vienoje galioje esant ịvairiems ipročiams pasitaiko nusidèti vieno, bet ne kito ịpročio veiksmu. Pavyzdžiui, jei gramatikos ir geometrijos žinovas, skelbdamas tiesą apie tieses, darytų sintaksės klaidą.

11. I vienuoliktajji atsakytina, kad jei tobulumas užbaigia tobulintino tobulinimą visu jo gebèjimu požiūriu, tai neįmanoma, kad vieno tobulintino įvairūs tobulumai priklausytu tai pačiai tvarkai. Ir todèl negali būti, kad medžiagą tuo pačiu metu tobulintų du esminiai pavidalai, nes ta pati medžiaga geba priimti tik vieną esminę esatį. Bet kitaip yra atveju atsitiktiniu pavidalu , kurie savo objektus tobulina ne pagal ju visą galia, todèl imanoma, kad daugybẻ atsitiktinių pavidalu priklausytu vienam, tobulèti galinčiam objektui. Ir todèl daugybè îpročiu gali priklausyti vienai galiai, nes galiu ịpročiai yra atsitiktiniai tobulumai, kadangi jie netikètai prisijungia prie galios išbaigtos prigimties.

12. I dvyliktaji atsakytina, jog kaip sako Avicena traktato Apie prigimtinius dalykus šeštojoje knygoje, veiksmų ìvairovè kartais rodo galių įvairovę, o kartais nerodo. Mat sielos veikloje įvairovę galima nustatyti penkiais būdais. Pirmu, pagal stiprumą ir silpnuma, kaip manyti ir tikèti. Antru, pagal greitumą ir lètuma, kaip bègti ir būti judinamam. Trečiu, pagal turëjimą ir stokojima, kaip būti ramybëje ir būti judinamam. Ketvirtu, pagal palyginimą su tos pačios giminès priešingybe, kaip matyti baltą ir matyti juodą. Penktu būdu tada, kai veiksmai priklauso skirtingoms rūšims, kaip suvokti ir judinti arba girdèti garsą ir matyti spalvą. Pirmuoju ir antruoju būdu nustatytas skirtingumas galiu skirtingumo nerodo todèl, kad jeigu rodytu, tai skirtingų sielos galiu turètų būti tiek, kiek yra stiprumo ir silpnumo laipsnių, arba tiek, kiek veiksmuose būna greičiu ir lètumų. Tą pati galima pasakyti ir apie trečiuoju bei ketvirtuoju būdu nustatytą skirtingumą, nes su abiem priešingybèmis susijusi ta pati galia. Tik penktuoju būdu nustatytas skirtingumas rodo galių skirtingumą taip, kaip sakome, kad skirtingoms giminèms priklauso tie veiksmai, kurie objekto pri- 
gimtyje nesusitinka. Ir todèl aukštesniojo ir žemesniojo proto veiksmų skirtingumas galiu ivvairovės nerodo, kaip matyti iš to, kas jau buvo sakyta.

13. I tryliktajij atsakytina, kad aktyvusis ir pasyvusis mąstymas skiriasi labiau, negu aukštesnysis ir žemesnysis protas, nes aktyvusis ir pasyvusis mąstymas mąsto savo pavidalais, jeigu ne medžiaga, skirtingus objektus. Mat jie apmąsto skirtingą objekto prigimti, nors abu gali veikti tame pačiame, nes tas pats daiktas gali būti pirmiau suprantamas galimai, o jau po to aktualiai. Tačiau aukštesnysis ir žemesnysis protas skirtingus objektus supranta pagal jų medžiaginę, o ne pavidalinę prigimti, nes, kaip iš to, kas jau pasakyta, matyti, skirtingas prigimtis mąsto pagal vieną objekto prigimti. Kadangi pavidalinis skirtingumas yra didesnis už medžiagini, argumento išvada nèra teisinga.

14. I keturioliktaji atsakytina, jog teigiama, kad žemesnysis protas kildinamas iš aukštesniojo, nes tų dalykų, kuriuos jis mąsto, prigimtis kildinama iš tų dalykŭ, kuriuos mąsto aukštesnysis protas: juk žemesniosios prigimtys kildinamos iš aukštesniujų Vadinasi, niekas aukštesniajam ir žemesniajam protui nekliudo būti viena galia taip, kaip matome, jog ta pati galia nagrinëja tiek aukštesniojo, tiek jam pavaldaus žemesniojo mokslo pradus, nors pastarieji kildinami iš pirmujų.

15. I penkioliktaji atsakytina, jog teigiama, kad aukštesnysis protas judina žemesnijji todèl, kad žemesniosios prigimtys yra tvarkomos pagal aukštesniąsias taip, kaip pavaldus mokslas tvarkomas valdančiuoju.

\section{Literatūra}

Aristotelis. 1990a. Apie sielą. Iš senosios graikų k. vertė Vosylius Sezemanas. Rinktiniai raštai: 321-405. Vilnius: Mintis.

Aristotelis. 1990b. Nikomacho etika. Iš senosios graiku k. vertė Jonas Dumčius. Rinktiniai raštai: 61-273. Vilnius: Mintis.

Aristotle. 1941c. Metaphysics. Tr. W. D. Ross. The Basic Works of Aristotle, ed. R. McKeon, New York: Random House.

\section{Nuorodos}

1 Šis žodis čia suprantamas kaip dedukcijai priešinga loginè operacija: dedukuoti - iš prielaidų daryti išvadas, redukuoti - patikrinti, ar išvados
Aristotle. 1941d. Physics. Tr. W. D. Ross at al. The Basic Works of Aristotle, ed. R. McKeon, New York: Random House.

Augustinus Aurelius. 1841a. De Trinitate, lib. XII, cap. 13, 20, PL, T. 42. Ed. Jacques Paul Migne. Paris. <https://www.augustinus.it/latino/trinita/ index2.htm> [žr. 202108 16]

atitinka prielaidas, pirmąsias suvedant atgal i prielaidas, pradmenis, principus.

Iš lotynų kalbos vertè prof. dr. Gintautas VYŠNIAUSKAS, Klaipėdos universitetas

Versta iš Sancti Thomae de Aquino Quaestiones disputatae de veritate, quaestio XV. Textum adaequatum Leonino 1972 edito ex plagulis de prelo emendatum ac translatum a Roberto Busa SJ in taenias magneticas denuo recognovit Enrique Alarcón atque instruxit https://www.corpusthomisticum.org/qdv15.html [žr. 202108 09] 